\title{
"Knowledge and technology transfer networking platforms in modern research universities"
}

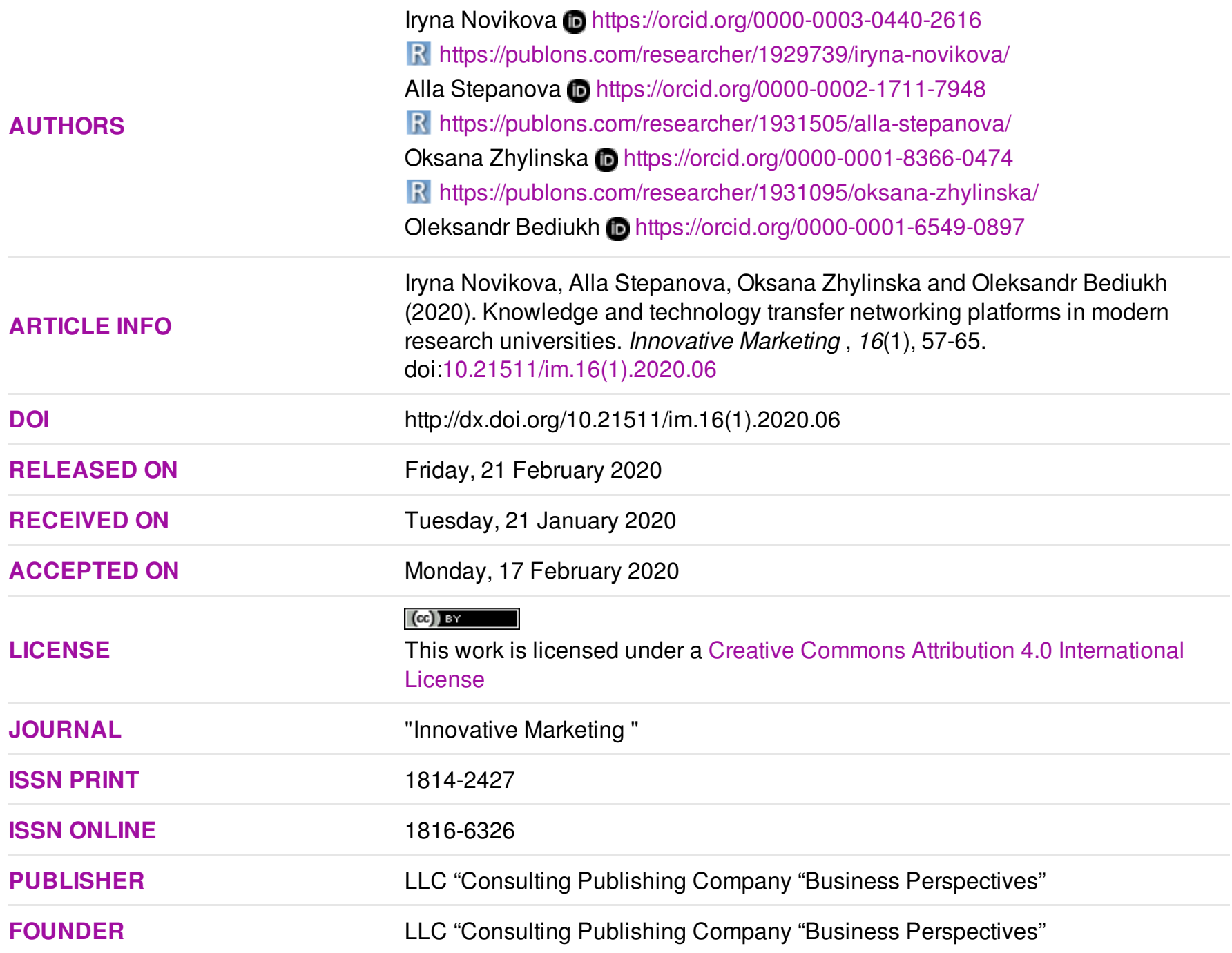

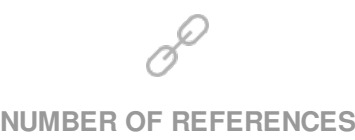

34
NUMBER OF FIGURES

0

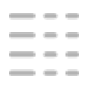

NUMBER OF TABLES

1

(C) The author(s) 2022. This publication is an open access article. 


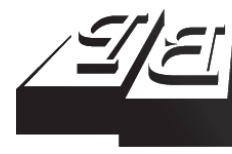

\section{BUSINESS PERSPECTIVES}

LLC "CPC "Business Perspectives" Hryhorii Skovoroda lane, 10, Sumy, 40022, Ukraine www.businessperspectives.org

Received on: $21^{\text {st }}$ of January, 2020 Accepted on: $17^{\text {th }}$ of February, 2020 Published on: $21^{\text {st }}$ of February, 2020

(C) Iryna Novikova, Alla Stepanova, Oksana Zhylinska, Oleksandr Bediukh, 2020

Iryna Novikova, Ph.D., Senior Researcher, R\&D Department, Taras Shevchenko National University of Kyiv, Ukraine.

Alla Stepanova, Ph.D., Associate Professor, Department of Innovation and Investment Management, Taras Shevchenko National University of Kyiv, Ukraine.

Oksana Zhylinska, Dr. Sc., Professor, Vice-rector for science, Taras Shevchenko National University of Kyiv, Ukraine.

Oleksandr Bediukh, Ph.D., Senior Researcher, Taras Shevchenko National University of Kyiv, Ukraine.

This is an Open Access article, distributed under the terms of the Creative Commons Attribution 4.0 International license, which permits unrestricted re-use, distribution, and reproduction in any medium, provided the original work is properly cited.

Conflict of interest statement: Author(s) reported no conflict of interest
Iryna Novikova (Ukraine), Alla Stepanova (Ukraine), Oksana Zhylinska (Ukraine), Oleksandr Bediukh (Ukraine)

KNOWLEDGE AND

TECHNOLOGY TRANSFER

NETWORKING PLATFORMS

IN MODERN RESEARCH

UNIVERSITIES

\begin{abstract}
Innovative development of Ukraine is possible due to the introduction of an effective mechanism for the promotion of commercially attractive scientific ideas and developments, which are produced at universities, into the domestic and international markets. It is extremely difficult for research universities to negotiate the transfer of their developments due to the lack of an extensive technology transfer infrastructure where an information system would be in place to exchange technological requests and proposals. The authors demonstrate a modern toolkit for the transfer of knowledge and technology, which is actively used by the international academic community and contributes to the consideration of modern specifics in the organization of innovative marketing in research universities. In the article, the authors analyze the role of social and communication tools, namely media and online social platforms, such as Instagram, Twitter, LinkedIn, or YouTube, or other communication search platforms, including Enterprise Europe Network in the technological transfer of world research universities and Ukrainian university practice. The dominance of positive features in the use of media tools for technology transfer proves its viability for the Ukrainian market. Using the tools of media sector it was proposed to develop a modern strategy for commercializing the results of innovative activities of research universities. The article offers considering the process of bringing to commercially attractive results of experimental research at universities based on the methodology of network marketing and education.
\end{abstract}

\section{Keywords}

innovation, knowledge transfer, technology transfer, mass media, research university

\section{JEL Classification I23, M38, O33}

\section{INTRODUCTION}

As a result of the last intellectual revolution, which led to an essential simplification of communication relations, the world has absorbed the process of globalization. The role of information in public life and its transformation into a major strategic product, possession and disposal of which provides key positions in the modern world is constantly growing. The current information space became an arena of struggle for leadership in international markets to achieve the strategic and tactical goals. That is why the majority of society, when charting building promising technological directions to marketing their products and services, goes hand in hand with debugging the process of raising the awareness about this know-how, primarily through the media. However, developing countries lack base knowledge about what tools and in what sequence it is better to use for diversification of economic infrastructure in the field of technology transfer in a continuous process of economic, conjuncture, and political change. Also, they lack the institutional mechanisms and skills to counteract the restrictions 
and pursue an effective policy of change in the realm of know-how. Of course, the main advantages in determining the direction of technological development are market incentives, the structure of regulations, the content and quality of research, education, and social values. However, the promotion is of special importance in achieving the success of inventions and developments. After all, the main limiting factor for progressive technological transformation in society is the level of entrepreneurial culture in which technologies are developed and used and in which the dissemination of information about research achievements and their business opportunities is not given enough attention.

The theoretical and practical aspects of technology transfer efficiency analysis and innovation diffusion are of interest to many researchers and scholars. However, it should be noted that each country has its own system of technology transfer tools that would contribute to its innovative development.

\section{THEORETICAL BASIS}

The diffusion of innovation theory, developed by EM Rogers in 1962, is one of the fundamental works on disseminating innovation. The researcher views the spread of innovation as a fivestep process, where members of similar social systems share ideas or products through different channels of communication. This process is a typical example of managerial decision-making because the individual has to accept the proposed as something new, innovative. All this is diffusion.

These five stages include knowledge, persuasion, decision, implementation, and validation. Knowledge fosters the interaction between developers and users of innovation, where universities are most often the former, while companies and government are the latter. The combination of innovation, university, and the company founder (Chais, Ganzer, \& Olea, 2017), has led to the transformation of applied research into technological innovation, which is driving the society to change.

There arises the question of forming quality infrastructure at universities, which would facilitate the coordinated work of all structural units for a high positive result. Thus, Weckowska (2015) researches University Technology Transfer Offices (TTOs) and considers available opportunities to facilitate the commercialization of research findings. The researcher draws on practical research in six UK WTO's to develop a modern concept of learning processes that would prove effective through commercialization practices, which, in turn, highlight two approaches to commercialization - transaction and relationship-oriented practices.
The transfer of innovation from universities to the masses requires the development of marketing strategies. Sytnytskyi and Varava (2012) demonstrated a comprehensive understanding of strategic marketing planning for of promoting the innovative products to the market and defined a methodology for evaluating the effectiveness of innovative products promotion, taking into account their attractiveness to end consumers. It is quite difficult to adapt foreign experience in the field of innovation to the realities of Ukraine, where there is an uncertain market environment of a transformational economy and the difficult situation of most domestic enterprises.

Some theoretical propositions of marketing models of the diffusion of innovations for the development and systematization of marketing activities, which would optimize transaction costs for commercialization of high-tech products and would contribute to the development of tools for assessing the market for high-tech products, were reflected in the work of Zhylinska and Firsova (2015).

It is worth noting that in Ukraine, such information tools are hardly used to build marketing strategies for technology transfer such as social media, namely social networks, diverse online platforms.

The use of digital platforms as a tool for the commercialization of innovation, the potential of the digital economy, and digital technologies have been explored in its entirety by Ihnatiuk and Honcharuk (2018). The revitalization of digital processes in Ukraine will contribute to the revitalization of business and the growth of public welfare in general. 
Kushnir (2018) in her monograph "Technology Transfer: Mechanisms and Instruments" examines the experience of leading countries in the development of mechanisms and tools to promote technology transfer in Ukraine. It describes the stages of creating and implementing the ASFIMIR system as the basis for building an information technology platform for technology transfer in Ukraine and argues for the use of the ASFIMIR system as an effective tool for international technology marketing.

The positioning of the university as a successful innovation center directly affects its competitiveness, outlines the main competitive advantages among other market participants for innovative products, and forms a positive brand. The importance of personal branding for promoting a professional image and maximizing the status of educational online startups was researched by Tatomyr (2018). After all, educational startups of companies with mass open online courses are increasingly resorting to marketing tools for positioning educational products and services, which allows them to occupy a relevant niche in the market of educational institutions of foreign countries.

\section{AIMS}

The article aims to identify effective tools for knowledge and technology transfer, as well as to analyze current trends in marketing and diffusion of innovation in research universities.

\section{RESULTS}

\subsection{Causes of "scientific wars" in the world of knowledge}

Modern techniques technology transfer on a commercial basis predict the expansion of new consumer markets and increased competition with existing firms that producing or implement similar or analogical technologies in a particular business segment.

That is why, despite the huge benefits of introducing new technological solutions in various aspects of human life, not all countries are interested in anything that enters their market.
After all, at the same time, no one can forbid new players to follow well-established techniques and methods for the full conquest of local competitors, and this often leads to negative irreversible consequences for local entrepreneurs. Universities as powerful hubs, which, for the sake of their prosperity, are also forced to take into account and be guided by the laws of market economy, are now in the midst of strategic wars between themselves and companies claiming leadership in high-tech industries. Now, there are many publications about "scientific wars" but they generally do not shed light on their true reason, namely, the struggle for capital.

\subsection{The key to the success of modern universities}

\subsubsection{The experience of Germany and the USA}

For most of its history, since the $11^{\text {th }}-12^{\text {th }}$ centuries, universities, mainly European ones, have only been involved in the transfer of knowledge. It was until in the $19^{\text {th }}$ century in Germany the universities were tasked with producing and disseminating knowledge. The new German model of university development proved to be very successful and soon began to be reproduced in the United States. Primary competition between universities for well-known lecturers has grown into a rivalry for investment. Now, US research universities have become the advanced, vital knowledge centers that work to increase the national and regional economy. The main indicator of their success is the number of Nobel Prizes received. Most attempts by other countries to replicate the success of the American university model through excessive centralization and bureaucracy have been fruitless. However, in recent years, the quality of research and teaching at East Asian universities has grown rapidly. These universities (especially in China) are looking to be the most successful in the future. Competitive wars in the global knowledge market require forecasting future challenges of universities and the willingness to respond to them.

In 2018, magazine Forbes drew the public's attention to the fact that smaller universities found it much harder to fight for a "place in the sun." They have to resort to optimizing their resources: to reduce teaching staff, to dump prices for educational services, to introduce online and summer training courses, to involve foreign students, to apply 
to large specialized consortia for transfer them at management affairs of their employees in the field healthcare, insurance, and retirement benefits.

During the last decade, universities in various levels and areas of development in many countries around the world have been working to develop effective competitive strategies to fight for the market. Usually, one more hears and knows about strategies that allow us to optimize the learning process and attract more students. In most of them, the strategic foundations for the development of science are laid superficially. However, now, the university's management is increasingly shifting its focus to producing effective innovation and research models and strategies for development universities. Today's world constantly absorbed the global problems in such spheres as global health care, energy, environment, nutrition, and social justice. Therefore, well-known modern research universities such as Harvard have increasingly used strategies in their activities that demonstrate their unprecedentedly important role in finding answers to meet the complex day-to-day public challenges to the humanity. Gradually, the public in developed countries realized that universities could be not only scientific centers for new discoveries (new treatments or products) but also catalysts for the development of new industries and actors that seriously influence the course of socio-economic policy. Now, in addition to strengthening the focus on extension opportunities research field in the universities research and innovation strategies, it actively involved not only attraction of students but also all other social groups (government/state, business, households, etc.) in the innovation process. Well thought-out innovative branding and marketing play an important role in this process.

\subsection{Basic tools of knowledge and technology transfer}

\subsubsection{Depending on the choice of strategy and method of advancement technology to the market, tools of the transfer are also chosen}

The main tools of knowledge and technology transfer are:

a) political, which are first and foremost used to overcome various of barriers (formation of opportunities for developing the innovative sphere: making appropriate legislative decisions; signing of long-term agreements on partnership and cooperation; changing the trade and foreign investment policy; seeking the possibilities of evaluating the technology by international organizations);

b) financial (allocation of funds for infrastructure development; grants, loans, and subsidies; purchase of equipment, software, and services; credit guarantees; indirect financial support for innovation in the private sector, etc.);

c) infrastructure (availability of specialized technology transfer offices; suitable premises, equipment, software, etc.);

d) management (formation and implementation of innovative strategies and entrepreneurial thinking in organizations/universities, institutional support, training on emerging technologies evaluate and manage);

e) qualification (availability of relevant qualification skills among specialists in innovation management);

f) information (professional scientific publications, promotion, advertising, the formation of a positive reputation, image, etc.);

g) communication (communication and partnership relations within the framework of the work of European programs, such as Enterprise Europe Network, etc., as well as organizing and participating in conferences, exhibitions, forums).

All these tools are very important for successful technology transfer. However, if one always hears about some of them, then one continues to pay no attention to others. In Ukrainian university practice, they are just beginning to work with some of the tools that have been used around the world for quite some time.

\subsection{Commercial aggression of the mass media}

It is well known that the success of new technology in the market depends to a large extent on the 
correct and timely way of transmitting the information about new knowledge and technologies. The rapid dissemination of information about new knowledge or achievements to the public makes it possible for the media. In providing the marketing support for valuable objects of intellectual work, aggressive, offensive media concept has a decisive role.

Aggressive offensive media has a decisive role in providing the marketing support for valuable intellectual assets. After all, in the international space, media structures transmit the streams of diverse information, which shapes the attitude of the public to a particular subject of discussion. The most common media in the world are television, press (newspapers, magazines, and books), radio, and Internet. Almost all of their key functions are utilized by using the information and communication tools in technology transfer through the media.

\subsection{Key functions of media}

By applying the information and communication tools in technology transfer by helping the media, almost all of their key functions are involved:

a) integrational (supports the entry of society into the information space);

b) socialization (promotes certain lifestyles as well as moral values);

c) communication (interactive communication on air allows people to express their point of view on a particular problem);

d) informational (satisfies the listener's need for information);

e) educational (acquisition of new knowledge);

f) organizational (encourages people to take action and to make decisions);

g) brought up (influences the formation of public opinion).

Even the entertainment function (helping to get away from daily problems and just relaxing) can be used thanks to cognitive programs or cartoons for children and adults.
All you need to do is creatively and interestingly submit the right information as a relevant display media product.

Currently, the top universities in the world are using almost all of these tools to disseminate the information about their scientific, educational, or management achievements, events, events, competitions, and more. So, since 2000, UCTV has been successfully operating at the University of California, a leading US research university, which brings together a dozen of campuses and three national laboratories. The main task of the TV channel is to demonstrate the power and versatility of this university. UCTV covers the teaching and research processes of its university, as well as shapes a culture of knowledge among people around the world. For a wide audience, UCTV represents a fairly broad range of programs on education, science, medicine and health care, arts, and music, social issues, business, and agriculture. Formats of these programs include documentaries, lecture courses, scientific symposia, artistic performances, and more. To provide important information to the public, the channel uses cable and online format, YouTube, iTunes, Roku, and mobile applications. Thus, UCTV disseminates important and interesting information far beyond its campuses. Also, UCTV covers and a specialized audience, in particular, teachers, broadcasting for them the professional training and seminars. Many other famous universities in the world have their TV channels. Leading research universities in the world publish their scientific journals and educational newspapers. However, as in any other segment of the market, the use of media technology has its advantages and disadvantages (Table 1).

\subsection{Social webs as a powerful tool for promoting the scientific results in research universities}

A powerful inexpensive practical communication tool that can and should be used to commercially promote technology and conduct relevant market research in the innovation market is social internet networks. In 2019, the Internet audience is 4.39 billion people, and 3.48 billion users are registered in social networks. A study by Social Media Examiner 2018 found that virtually all marketers now use social networks to sell products or servic- 
Table 1. Main advantages and disadvantages of using mass media for commercial promotion of university technologies

Source: Developed by the authors.

\begin{tabular}{|c|c|c|}
\hline \multirow{2}{*}{ The media } & \multicolumn{2}{|c|}{ Table column head } \\
\hline & Advantages & Disadvantages \\
\hline TV & $\begin{array}{l}\text { - The largest of different ages and multigroup of } \\
\text { viewership } \\
\text { - The best resource for creating a presented image } \\
\text { - The most effective influence on human consciousness } \\
\text { through various senses (sight and hearing) } \\
\text { - The possibility of instant communication reaction on } \\
\text { the information }\end{array}$ & $\begin{array}{l}\text { - } \text { Media is expensive to use } \\
\text { greatest } \\
\text { Time waiting for information is long, it can reach several } \\
\text { months } \\
\text { - The information provided is fleeting } \\
\text { centralized power supply }\end{array}$ \\
\hline Press & $\begin{array}{l}\text { - Ease of use, because readers can anywhere } \\
\text { - The reader receives comprehensive composite } \\
\text { information } \\
\text { - The ability to use this information at a convenient time } \\
\text { - No need for special equipment } \\
\text { - The ability to save information for reuse }\end{array}$ & $\begin{array}{l}\text { - Considerable costs for printing print runs } \\
\text { - } \text { - Difficulties in quickly reaching a wide audience } \\
\text { - In remote settlements, there may be no delivery }\end{array}$ \\
\hline Radio & $\begin{array}{l}\text { - The wide reach of the audience (radio can listen even to } \\
\text { - } \text { the illiterates and the blinds) } \\
\text { - Relatively inexpensive to use (even those who have no } \\
\text { money for other information means can afford it) } \\
\text { - To prepare radio commercials easier, faster and } \\
\text { cheaper than television commercials } \\
\text { - The ability to target a specific audience by choosing the } \\
\text { - type of radio station } \\
\text { - The ability to quickly publish interesting information } \\
\text { - The radio signal extends over longer distances } \\
\text { - Can operate without a centralized power supply }\end{array}$ & $\begin{array}{l}\text { - Information is fleeting } \\
\text { - Usually, information messages are submitted in brief, so } \\
\text { they are ignored and forgotten } \\
\text { - There is a need to repeat important information } \\
\text { Often listeners perceive the radio as a pleasant sound } \\
\text { background and do not listen to it carefully, so the actual } \\
\text { size of the audience being covered may be negligible } \\
\text { Lack of visual image does not allow us to transmit many } \\
\text { details }\end{array}$ \\
\hline Internet & $\begin{array}{l}\text { - The wide reach of the target audience } \\
\text { - The cheapest resource to use } \\
\text { - Establishing visual and verbal communication with the } \\
\text { target audience } \\
\text { - Dissemination of necessary information is instant } \\
\text { - The ability to view information that has interested many } \\
\text { times }\end{array}$ & $\begin{array}{l}\text { - Need to purchase appropriate equipment and its } \\
\text { maintenance } \\
\text { In remote from civilization areas there may be difficulties } \\
\text { with access to the internet } \\
\text { - From the perception of a large amount of information, } \\
\text { attention is somewhat dissipated }\end{array}$ \\
\hline
\end{tabular}

es, develop their businesses, and make important decisions. The main advantages of using social internet networks in tradable marketing are that they allow you to achieve better customer interaction, increase product sales, quickly follow and respond to consumer sentiment, increase and improve business partnerships, and more. It is undoubted that direct communication with potential consumers, partners or investors gives greater results in promoting the products on the market. Posts on social networks than have target nature can create target groups, which provides more concentrated information messages about a specific product or service. Also, to attract the attention of social network users to the product, marketers often resort to holding the competitions and formation of special offers, the disclosure of evidence to generate trust in the product, direct advertising, etc.
Today, the common social media platforms used by marketers are Facebook and Instagram. Facebook's share in the global marketplace is $67 \%$. It is currently the primary platform for marketers. According to official information on Facebook, as of December 31, 2018, there were 1.52 billion active users in the world who visit the website at least once a day, and 2.23 billion at least once a month. Instagram is a promising social network that has become a business platform for comfortable communication between brands and users. Instagram ended 2018 with more than 1 billion users. Instagram has over 2 million monthly advertisers and 25 million business profiles. It is estimated at the end of $2018,71 \%$ of US businesses were on Instagram. Twitter has about 320 million users who can post tweets of up to 280 characters. Twitter is a very popular celebrity website, but you can also post information about your business, 
promotions, or special offers. Therefore, Twitter is a fantastic tool for building a brand and giving it a distinctive personality. Another professional website that is considered to be the largest audience of influential professionals in one place in the world and successfully used for product marketing is LinkedIn. More than 3 million companies are registered on LinkedIn. By constantly updating through LinkedIn, a company can tell more about itself or its products than through a branded site. And this better attracts potential partners and customers. In addition, marketing on LinkedIn is relatively inexpensive and therefore generates a lot more profit on the dollar spent on it. In total, today there are about 200 popular websites in the world and this list continues to grow. Most of these sites have many built-in tools that allow you to evaluate personal page analytics, identify trends, and better understand your customers. A great way to disseminate information about an organization (university) and product offering to customers (inventions and developments) is a video option on YouTube. It is currently the most popular social media resource in the business for advertising demonstrations. As of the end of 2018, YouTube had over 1 billion socially active users (mostly 1834 years old) in 91 countries.

\section{DISCUSSION}

Currently, the world leading universities have successfully used (including for the promotion and transfer of technology) such as popular social networking websites as Facebook, Instagram, Twitter, LinkedIn, and YouTube. These social networks allow individuals or groups of people to share ideas, images, videos, etc. in virtual communities. So, there are endless opportunities for Facebook to promote any business, especially where product visualization and public confirmation of the qual- ity of the goods or services received are required. Almost all the top universities in the world, including the University of Cambridge, Harvard University, and the University of Oxford, have pages on this and other social networks. They publish information about new research achievements and other professional achievements of their employees and graduates, scholarships, competitions, forums, donations, and more. In doing so, they form a clear view of the audience that the research of their talented scientists is really helping to improve the lives of millions of people around the world by addressing real-world problems. Due to this approach, taxpayers in such countries do not question why the state spends considerable financial resources on research and development. In addition, through social networks, new contacts, partnerships, and ways of cooperation are developed.

Thought leaders are those who first create or become familiar with media content and interpret it in their thoughts. Subsequently, such thoughts spread to the general public, which becomes a follower of thought.

The importance of social networks for the additional involvement of the audience, namely potential students, listeners, or researchers, is also recognized in Ukraine. Many well-known Ukrainian universities have already been featured on Facebook, Instagram, LinkedIn, or Twitter. One of the first Facebook pages was created by the most powerful university in the country, Taras Shevchenko National University of Kyiv.

Today, both the scientific community and governmental institutions are working to find effective strategies to activate the commercialization of intellectual work outcomes in Ukrainian universities.

\section{CONCLUSION}

In order to better position the market for inventive products (new technology, ideas, or services), market segmentation is applied, based on the social stratification of consumers - an association of goods with the social class of consumers based on the definition of relevant indicators (education, income, age, gender). As current society has an excess supply of goods on the market, the know-how life cycles are becoming shorter. On the one hand, most innovative products are commercially unsuccessful, but, on the other hand, most of the profits come from new products. The impact of mass communication, in 
particular through social networks, on users is also through a type of marketing as an outreach that allows you to promote your ideas results through building the relationship between them.

It is worth noting, apart from the tools of the mass media, that the platforms that unite universities, business, and government remain fundamental. To systematize existing innovation data and disseminate it worldwide, there are a significant number of technology transfer structures. All these associations, research and development centers, business structures are unified to the fullest extent and form international network structures, including Enterprise Europe Network (EEN).

The constant growth of knowledge transfer and innovation activities is key to overcoming the underdeveloped domestic economy. It is the authors' understanding of the theoretical relationship between the transfer of knowledge, technology, and the dynamics of social networks, and the intensification of the use of Internet platforms that will promote the results of innovative activities of Ukrainian universities.

\section{Author Contributions:}

Conceptualization: Iryna Novikova, Alla Stepanova, Oksana Zhylinska, Oleksandr Bediukh.

Methodology: Iryna Novikova, Oksana Zhylinska.

Visualization: Iryna Novikova, Alla Stepanova, Oksana Zhylinska, Oleksandr Bediukh.

Writing - original draft: Iryna Novikova, Alla Stepanova, Oksana Zhylinska, Oleksandr Bediukh.

Writing - review \& editing: Alla Stepanova.

\section{REFERENCES}

1. Atkinson, R. C., \& Blanpied, W. A. (2008). Research Universities: Core of the US science and technology system. Technology in Society, 30, 30-48. Retrieved from http://www.rca.ucsd.edu/docs/ TIS_Research\%20Universities\%20 Core\%20of\%20the\%20US\%20science $\% 20$ and $\% 20$ technology $\% 20$ system.pdf

2. Bianchi, M., Di Benedetto, A., Franzò, S., \& Frattini, F. (2017). Selecting early adopters to foster the diffusion of innovations in industrial markets: Evidence from a multiple case study. European Journal of Innovation Management, 20(4), 620-644. https://doi. org/10.1108/EJIM-07-2016-0068

3. Brand, A. (2009). Medien-DiskursWeltpolitik. Wie Massenmedien die internationale Politik beeinflussen (Zugl. Diss.). Technische Universität Dresden.

4. Chais, C., Ganzer, P. P., \& Olea, P. M. (2017). Technology transfer between universities and companies: two cases of Brazilian universities. Innovation \& Management Review, 15(1), 20-40. http://dx.doi. org/10.1016/j.rai.2017.07.003

5. Chan, J. (2018). 3 strategies universities are using to tackle societal challenges. Retrieved from https:// www.elsevier.com/connect/3strategies-universities-are-usingto-tackle-societal-challenges

6. Cripps, C. (2017). International strategy for universities: 10 keys to success. Retrieved from https:// www.timeshighereducation.com/ blog/international-strategy-universities-10-keys-success

7. EBA (2018). LinkedIn for Business: Everything You Need to Know. Retrieved from https://eba.com.ua/ article/linkedin-dlya-biznesu-vseshho-vam-potribno-znaty/

8. FATbit (n.d.). Creative Ways to Promote Your Product on Social Media. Retrieved from https:// www.fatbit.com/fab/6-creativeways-promote-product-socialmedia/

9. Harry Collins. (n.d.). The Science Wars. Retrieved from https://sites. cardiff.ac.uk/harrycollins/thescience-wars/

10. Ihnatiuk, A. I., \& Honcharuk, I. V. (2018). Konkurentsiia platform v umovakh tsyfrovizatsii ekonomiky Ukrainy [Competition of platforms in conditions of Ukrainian economy digitalization]. In Ekonomichna stratehiia ta polityka realizatsii yevropeiskoho vektoru rozvytku Ukrainy: kontseptualni zasady, vyklyky ta protyrichchia: monohrafiia [Economic strategy and policy for realizing the European vector of Ukraine's development: conceptual bases, challenges and contradictions] (pp. 378-405). Kyiv: Nichlava.

11. Ivan, L. (2019). Effective Higher Education Marketing Strategies for 2019. Retrieved from https://www. theseventhsense.com/blog/10effective-higher-education-marketing-strategies-for-2019

12. Kemp, S. (2019). Digital 2019: Global internet use accelerates. Retrieved from https:// wearesocial.com/blog/2019/01/ digital-2019-global-internet-useaccelerates

13. Korek, W. (2012). Instrumente des technologietransfers europäische life science cluster im vergleich. Retrieved from https://www. technologiestiftung-berlin.de/ fileadmin/daten/media/publikationen/Archiv/120601_Studie_Instrumente-Techtransfers.pdf

14. Kushnir, H. L. (2018). Transfer tekhnolohii: mekhanizmy ta instrument [Technology transfer: mechanisms and instrument (260 p.) Kyiv: UkrINTEI. (In Ukrainian). 
15. Lapovsky, L. (2018). The Changing Business Model For Colleges And Universities. Retrieved from https://www.forbes.com/sites/lucielapovsky/2018/02/06/the-changing-business-model-for-collegesand-universities/\#773c06f95ed5

16. More, R. A. (1983). Overcoming Barriers to the Adoption of High Technology in Industrial Markets. Business Quarterly (Winter), 110-116.

17. Nason, H. K. (1977). Perception of Barriers to Innovation. Research Management, 20(1), 17-20.

18. OMNICORE (2020). Instagram by Numbers: Statistics, Demograph$i c s$, and Fun Facts. Retrieved from https://www.omnicoreagency.com/ instagram-statistics/

19. Rogers, E. M. (1983). Diffusion of Innovations. New York: The Free Press.

20. Social Innovation Community (SIC) (2018). Introduction to social network analysis. Retrieved from https://www.siceurope. $\mathrm{eu} /$ sic-themes/education/ introduction-social-networkanalysis?conical=true

21. Social Media List (n.d.). Top 200 social media sites for 2018. Retrieved from https://socialmedialist.org/spysok-sotsialnykh-merezh. html

22. Stelzner, M. (2019). Social media marketing industry report. How Marketers Are Using Social Media to Grow Their Businesses. Social Media Examiner. Retrieved from https://www.socialmediaexaminer. com/social-media-marketingindustry-report-2019

23. Sytnytskyi, M., \& Varava, Yu. (2012). Stratehichne marketynhove planuvannia protsesiv prosuvannia innovatsiinoi produktsii na rynok [Strategic marketing planning of the processes of innovative products promotion to the market]. Visnyk Kyivskoho natsionalnoho universytetu imeni Tarasa Shevchenka. Ekonomika - Herald of Taras Shevchenko National University of Kyiv. Economics, 136, 50-54. (In Ukrainian).

24. Taras Shevchenko National University of Kyiv. (n.d.). Official Facebook page. Retrieved from https://www.facebook.com/kyiv. university/?_tn__ $\% 2 \mathrm{CdK}-\mathrm{R}-\mathrm{R} \&$ eid=ARBbTkP73jyJAxPZhOMaZ8 BZQABtIwXUqio9lnwqmdk-3Dt0we8BznDxIIaRICDG2B0KJe6t4 Ghi6zI\&fref=mentions

25. Tatomyr, I. L. (2018). Marketynhovi metody prosuvannia profesiinoho brendu kompanii MVOK [Marketing methods of MVOK company professional brand promotion]. Ekonomichnyi dyskurs

- Economic discourse, 1, 24-32. (In Ukrainian). Retrieved from http://188.190.33.55:7980/jspui/ bitstream/123456789/6784/1/ ED\%202018\%281\%29.24-32.pdf

26. The Harvard University (n.d.). Official Facebook page. Retrieved from https://www.facebook.com/ Harvard

27. The University of Cambridge. (n.d.). Official Facebook page. Retrieved from https://www.facebook.com/cambridge.university/

28. The University of Oxford. (n.d.). Official Facebook page. Retrieved from https://www.facebook.com/ the.university.of.oxford

29. Tsiupyn, B. (2018).Facebook sviatkuie 15-richchia i obitsiaie zakhyshchaty vybory $v$ Ukraini [Facebook celebrates 15-year anniversary and promises to ptotect the elections in Ukraine]. (In Ukrainian). Retrieved from https://ukrainian.voanews. com/a/facebook-15/4771409. html?fbclid=IwAR3eVNmjc95Afh9PmiEc75nMXH-PFUxZBZnD77Bur0I-OSrJvgMRTBzWeA

30. University of California Television (UCTV). Official TV channel. Retrieved from https://www. uctv.tv/about/

31. Weckowska, D. M. (2015). Learning in university technology transfer offices: transactionsfocused and relations-focused approaches to commercialization of academic research. Technovation, 41-42, 62-74. http:// doi.org/10.1016/j.technovation.2014.11.003

32. Wikipedia (n.d.). Science Wars. Retrieved from https://
en.wikipedia.org/wiki/Science_wars

33. YouTube for the press. (n.d.). Official website. Retrieved from https://www.youtube.com/intl/ uk/yt/about/press/

34. Zhylinska, O., \& Firsova, S. (2015). Vytraty komertsializatsii naukoiemnoi produktsii u konteksti marketynhovoi modeli difuzii innovatsii [Costs for commercionalization of science products in the context of innovation diffusion marketing model]. Visnyk Kyivskoho natsionalnoho universytetu imeni Tarasa Shevchenka. Ekonomika - Herald of Taras Shevchenko National University of Kyiv. Economics, 32(172), 6-14. (In Ukrainian). Retrieved from https://cyberleninka.ru/article/n/ vitrati-komertsializatsiyi-naukoemnoyi-produktsiyi-u-konteksti-marketingovih-modeleydifuziyi-innovatsiy 